\title{
MODERNISASI POLITIK SISTEM PEMERINTAH KECAMATAN MAJALAYA KABUPATEN BANDUNG TAHUN 2012
}

\author{
Neneng Yani Yuningsih \\ e-mail: nenengyanyyahoo.co.id
}

\begin{abstract}
ABSTRAK
Penelitian ini dilatarbelakangi oleh kondisi kedudukan Pemerintah Kecamatan dalam penyelenggaraan sistem pemerintahan di Indonesia. Menurut UU 32/2004 tentang Pemerintahan Daerah, pemerintah kecamatan merupakan perangkat pemerintah kabupaten dan/atau pemerintah kota. Sehingga dalam penyelenggaraan otonomi daerah, pemerintah kecamatan mendapat pelimpahan tugas, fungsi, dan kewenangan yang luas dari pemerintah kabupaten. Akan tetapi, pelimpahan tersebut tidak disertai dengan perbaikan sumber daya baik secara suprastruktur maupun infrastruktur. Apalagi karakteristik wilayah Kecamatan Majalaya yang merupakan wilayah pengembangan industri di Kabupaten Bandung, sehingga pemerintah harus dikondisikan untuk menjadi bagian dalam proses industrialisasi. Salah satu tunt utan dalam proses industrialisasi adalah melakukan upaya modernisasi politik pada sistem pemerintah kecamatan. Temuan hasil penelitian di lapangan menunjukkan bahwa Pemerintah Kecamatan Majalaya sesungguhnya memiliki kesiapan suprastruktur dalam proses modernisasi politik. Akan tetapi dari segi kesiapan infrastruktur, Kecamatan Majalaya belum mengalami modernisasi politik, karena pemberdayaan masyarakat belum dimanfaatkan oleh Ormas/LSM, pemerintah, maupun masyarakat itu sendiri. Adapun partisipasi masyarakat dalam melakukan aktivitas-aktivitas politik, terutama terkait dengan keberadaan partai politik, cukup memadai sebagai syarat modernisasi politik.
\end{abstract}

Kata Kunci: Modernisasi Politik, Pemerintah.

\section{ABSTRACT}

This research is performed due to the current condition of the position of Subdistrict Government in the implementation of governmental system in Indonesia. According to the Regulation 32/2004 regarding Local Government Autonomy stipulating that the Sub-district Government constitutes part of Regency Government and/or City Government. Therefore in the implementation of Local Government autonomy, the Sub-district Government will have governmental task delegation, 
wider function, and authorities from the Regency Government. Nevertheless, the authorities delegation is not accompanied by the improvement of the resources of suprastructure and infrastructure. Moreover the characteristic of the Sub-district Majalaya is the area in the Regency of Bandung which is developed as an industrial area, therefore the Government has to be conditioned as part of industrilization process. One of the important demands in process of industrilization is to make effort to modernize political and Sub-district governmental system. The outcome of the research reveals that the Sub-district Government of Majalaya actually has the suprastructural readiness to implement political modernization. But in terms of infrastructure readiness, the Sub-district Majalaya has not performed political modernization yet, this is due to the society empowerment trough the nongovernmental organization is not yet taken advantage of by those non-governmental organization, by the government or by society themselves. The participatison of the society in the implementation of the political activities is still related to the existing of political parties which is considered adequate as condition for the political modernization.

Keywords: Political Modernization, Government.

\section{PENDAHULUAN}

Dalam menganalisis perkembangan politik, para peneliti modernisasi politik pada pokoknya memandang kehidupan politik yang menjadi objek studinya dalam suatu kerangka yang dinamakan sistem politik, yaitu terdiri dari struktur dan proses politik. Struktur politik adalah kelompok atau organisasi politik yang dapat terdiri dari unsur organisasi negara ataupun organisasi masyarakat, sementara proses politik adalah interaksi antarstruktur tersebut dalam menjalankan fungsinya masing- masing ${ }^{92}$. Penyusunan struktur politik dengan fungsinya yang khusus dan tingkat kemampuan struktur tersebut melaksanakan fungsinya merupakan hal yang disoroti di dalam proses modernisasi politik ${ }^{93}$

Modernisasi adalah sejenis harapan yang khusus, melekat di dalamnya adalah seluruh revolusi masa lampau serta seluruh keinginan manusiayang paling tinggi. Sementara di sisi lain, industrialisasi yang merupakan kebanggaan bagi negara kaya dan negara kuat serta menjadi harapan bangsa-bangsa miskin dan

92 AFK. Organski; Tahap-tahap Perkembangan Politik. Akademika Pressindo, Jakarta. tahun 1985, hal. XXIX

93 Ibid., hal. XXIX-XXX. 
terbelakang, memberikan suatu tantangan luar biasa bagi sistem politik bangsa dan negara manapun ${ }^{94}$. Industrialisasi ini senantiasa menjadi bagian integral dari modernisasi, tetapi industrialisasi hanya merupakan salah satu aspek modernisasi. Adapun aspek dasar modernisasi, menurut Huntington, ${ }^{95}$ adalah urbanisasi, industrialisasi, sekularisasi, demokratisasi, dan peran-serta media massa. Pentingnya studi tentang modernisasi (politik) terutama sebagai sarana untuk mengidentifikasipengaturan-pengaturan sosial yang membantu atau merintangi industrialisasi dan sebagai sarana untuk mengamati bagaimana perubahan disesuaikan atau menuju perubahan yang lebih baik.

Modernisasi politik terkait dengan struktur dan fungsi yang berlaku dalam suatu sistem, seperti halnya dalam sistem pemerintahan kecamatan yang menjadi fokus utama dalam penulisan ini. Undang-Undang (UU) No. 32 Tahun 2004 tentang Pemerintahan Daerah pasal 126 menguraikan bahwaKecamatan adalah wilayah kerja camat sebagai perangkat Daerah Kabupaten dan Daerah Kota.
Sementara dalam penjelasannya diuraikan bahwa Kecamatan yang menurut UU Nomor 5 Tahun 1974 sebagai wilayah administrasi dalam rangka dekonsentrasi, menurut UU No.32 Tahun 2004 kedudukannya diubah menjadi perangkat daerah kabupaten atau daerah kota.

Adapun karakteristik Kecamatan Majalaya sebagai obyek dalam penelitian ini, merupakan wilayah pembangunan yang memiliki potensi industri. Selain itu, karakteristik sebagai wilayah industri dapat dicermati pada perkembangan industri yang mengalami pasang surut dalam pertumbuhannya. Data monografi Kecamat an Majalaya Semester I Tahun 2012 menunjukkan bahwa jumlah industri yang terdapat di Kecamatan Majalaya sebanyak 293 buah. Industri tersebut terbagi ke dalam kategori industri besar dan industri sedang sebanyak 129 buah dan industri kecil sebanyak 164 buah. Kondisi tersebut menunjukkan peningkatan jika dibandingkan dengan tahun 2011 dimana jumlah industri kecil sebanyak 103 buah sementara tahun 2010 dan 2009 berjumlah 101 buah $^{96}$.

94 Ibid., hal. 62.

95 Samuel P. Huntington; Tertib PolitikdiTengah Pergeseran Kepentingan Massa.PT. RajaGrafindo Persada; Jakarta, tahun 2003, hal. 46.

96 Data Potensi Perusahaan Industri Manufaktur Formal Non Fasilitas di Kabupaten Bandung tahun 2012. Dinas Perindustrian dan Perdagangan Pemerintah KabupatenBandung. Sementara untuk industri sedang dan besar, penulis mengalami kesulitan dalam memperoleh data karena sejak pemberlakuan otonomi daerah sekitar tahun 2000, pelimpahan wewenang dari Pemerintah Daerah Provinsi Jawa Barat (Departemen Perindustrian dan Perdagangan Provinsi Jawa Barat) kepada Pemerint ah Kabupaten Bandung tidak disertai dengan pelimpahan data-data. Sementara, di Departemen Perindustrian dan Perdagangan Provinsi Jawa Barat pun tidak memiliki datadata mengenai jumlah industri dan perkembangannya. 
Kategorisasi industri dapat ditelusuri dari jumlah investasi pada industri tersebut. Untuk kategori industri kecil jumlah investasinya di bawah 200 juta rupiah, untuk industri sedang dilihat dari jenis usaha yang memiliki investasi di atas 200 juta sampai 1 miliar rupiah. Sementara untuk industri besar, jumlah investasi di atas 1 Miliar rupiah. Sebelum otonomi daerah, kewenangan pengelolaan industri sedang dan besar berada pada Pemerintah Daerah Provinsi (Departemen Perindustrian dan Perdagangan Provinsi Jawa Barat), sementara pengelolaan industri kecil menjadi tanggung-jawab pemerintah kabupaten (Pemkab Bandung).

Adapun pemerintah kecamatan tidak memiliki kewenangan maupun tanggung-jawab langsung dalam pengelolaan industri. Kondisi ini selaras dengan kedudukan pemerintah kecamatan seperti dijelaskan dalam UU tentang Pemerintahan Daerah tersebut,dimanapemerintahkecamatan merupakan perangkat dari pemerintah kabupaten dan pemerintah kota. Sementara camat sebagai kepala kecamatan hanya menerima pelimpahan kewenangan pemerintahan dari Bupati/Walikota. Padahal pada kenyataannya kecamatan merupakan wilayah yang memiliki kedekatan langsung dengan masyarakat, sehingga pemerintah kecamatan memiliki pemahaman yang lebih mendalam tentang kondisi dan potensi wilayah dan masyarakatnya. Dengan terbatasnya kewenangan di dalam pembangunan(industri), inimenyebabkan Pemerintah Kecamatan Majalaya terbatas dalam inisiatif pengembangan potensi (industri) diwilayahnya.

Secaraformal,StrukturOrganisasi Tata Kerja (SOTK) Pemerintah Kecamatan Majalaya memiliki kondisi struktural dan fungsional yang memadai untuk pengembangan wilayah maupun pemberdayaan masyarakat. Pemerintah Kecamatan Majalaya terdiri dari Camat, Sekretaris Kecamatan, dan 7 Seksi, yaitu Seksi Perencanaan, Seksi Pemerintahan, Seksi Pengendalian Ketentraman dan Ketertiban, Seksi Pemeliharaan Sarana Umum, Seksi Pemberdayaan Masyarakat, Seksi Pengembangan Potensi PAD, serta Seksi Informasi dan Kehumasan.

\section{TINJAUAN TEORETIS}

\section{Modernisasi Politik}

Masalah pokok dan yang paling sering dipandang sebagai faktor khusus yang terdapat di dalam proses modernisasi politik adalah pergeseran masyarakat tradisional menuju masyarakat modern. Masyarakat yang telah menjadi modern dicirikan oleh keterbukaan dan persaudaraan yang mencerminkan penghargaan pada publik serta penghargaan terhadap kemampuan manusia. Sehingga, ciri pemerintah lebih merupakan agen aktif daripada pasif yang mencerminkan masyarakat seperti apa adanya. 
Pemerintah membantu membentuk masyarakat yang sesuai dengan normanorma partisipasi dengan menekankan tujuan untuk menyadari kemampuan manusia dan sumber daya sosial. Dalam bukunya, "Tertib Politik: di Tengah Pergeseran Kepentingan Massa”, Huntington merumuskan tiga pola atau tiga kategori utama modernisasi politik, yaiturasionalisasi wewenang, diferensiasi struktur, dan perluasan peran-serta di bidang politik.

Pertama, modernisasi politik melibatkan adanya rasionalisasi kekuasaan, pergantian sejumlah besar pejabat-pejabat politik tradisional, etnis keagamaan, kekeluargaan oleh kekuasaan nasional yang bersifat sekuler. Perubahan ini menunjukkan bahwapemerintahanadalahmerupakan produk kerja manusia, bukan hakekat alam ataupun Tuhan, sehingga tertib sosial yang baik harus mengandung ukuran sumber daya manusia yang tetap sebagai kekuasaan akhir dan takluk pada aturan hukum positif di atas segala peraturan yang ada.

Kedua, modernisasi politik melibatkan diferensiasi fungsi politik yang baru dan pengembangan struktur khusus sebagai pelaksanaan seluruh fungsi tersebut. Hierarki administrasi menjadi kian terperinci dan tegas, kompleks serta lebih disiplin, jabatan dan kekuasaan didistribusikan dengan bersandar pada ukuran prestasi bukan askripsi.

Ketiga, modernisasi politik ditandai dengan meningkatnya peranserta politik yang meliputi seluruh lapisan masyarakat. Mendalamnya partisipasi di bidang politik ini dapat meningkatkan kadar kontrol penguasa atas masyarakat seperti pada negara totaliterataumempertegaspengawasan massa atas pemerintah seperti dalam sistem demokrasi. Namun dalam semua negara modern, warga negara secara langsung terlibat dalam mempengaruhi pemerintahan. ${ }^{97}$

\section{Kategorisasi Modernisasi Politik}

Sejumlah ahli merumuskan berbagai pola atau kategori khusus dari modernisasi politik. Welch ${ }^{98}$ memberikan tiga ciri pokok proses modernisasi politik. Pertama, peningkatan pemusatan kekuasaan tradisional; Kedua, diferensiasi dan spesialisasi lembaga-lembaga politik; Ketiga, peningkatan partisipasi rakyat dalam politik dan kesediaan individuindividu untuk mengidentifikasikan diri dengan sistem politik sebagai satu keseluruhan. Sementara bagi Apter ${ }^{99}$, modernisasi politik mengandung tiga kondisi. Pertama, suatu sistem sosial

97 Huntington. Op.Cit. hal. 42-43.

98 Yahya Muhaimin \& Colin MacAndrews. Op.Cit. hal. 34.

99 David E. Apter. Op.Cit. hal. 72. 
yang secara terus-menerus dapat berinovasi tanpa menjadi terpecah, termasuk di dalamnya kepercayaankepercayaan pokok mengenai perubahan yang bisa diterima; Kedua, struktur sosial yang fleksibel dan terdiferensiasi; Ketiga, suatu kerangka acuan sosial yang menunjang keahlian serta pengetahuan yang dibutuhkan untuk hidup di dalam suatu dunia dengan teknologi yang sangat maju.

Bagi Organski ${ }^{100}$, corak kehidupan masyarakat dan politik yang perlu diraih oleh masyarakat yang sedang berkembang dalam perjalanannya ke arah modernisasi politik adalah melalui industrialisasi, rasionalisasi, sekularisasi, pragmatisme, liberalisasi, dan sebagainya sebagai buah karya ahli kemasyarakatan Barat. Di dalam kehidupan politik, corak kehidupan sosial tersebut diwujudkan dalam unsur-unsur demokrasi seperti distribusi kekuasaan, pengawasan terhadap pemegang kekuasaan, diferensiasi dan spesialisasi struktur serta fungsi politik, partisipasi politik masyarakat luas, stabilitas politik dan perubahan politik dalam kesinambungan. Sekalipun peranan ekonomi penting dalam kerangka pikir modernisasi politik, tetapi hal itu dianggap sebagai sarana bagi proses pendidikan dan pengalaman, bukan sebagai mekanisme perubahan politik.

\section{Rasionalisasi Wewenang}

Modernisasi politik memerlukan wewenang untukperubahan, sementara perubahan mendasar yang terjadi dalam masyarakat dan politik bersumber dari tindakan manusia yang selalu mempunyai tujuan. Artinya, wewenang harus terdapat di dalam diri manusia. Selain itu, manusia juga harus mempunyai kekuasaan untuk mempengaruhi perubahan. Maka, wewenang harus dipusatkan di dalam individu atau kelompok individu tertentu. Berbeda dengan masyarakat politik tradisional, masyarakat politik modern memiliki ciri-ciri kewenangan yang didasarkan pada prinsip rasio, struktur yang rumit, partisipasi massa rakyat, dan sebagai konsekuensinya, kemampuan mencapai sejumlah besar tujuan-tujuan nasional bersama.

Pada abad dua puluh ${ }^{101}$, meluasnya partisipasi dan rasionalisasi wewenang berlangsung serempak. Ini berarti bahwa wewenang harus dipusatkan di dalam partai politik atau tokoh pimpinan yang memiliki kharisma di kalangan rakyat banyak. Kedua hal tersebut harus mampu baik menggugah massa maupun memberikan tantangan bagi sumber wewenang tradisional. Modernisasi politik yang diadopsi oleh masing-masing masyarakat sering ditentukanolehpartai-partainya.Kalau

100 A.F.K Organski. Op.Cit. XXXVIII-XXIX. 101 Samuel P. Huntington. Op.Cit. hal 118. 
partai politik menjadi teratur di suatu masyarakat yang sedang menjadi modern, partai-partai tersebut akan terlibat di dalam beragam aktivitas termasuk untuk menumbuhkan minat politik masyarakat. Peran penting partai politik di dalam masyarakat yang sedang menjadi modern adalah kemampuannya dalam mengisi kepuasan psikis. Hal ini membuat partai politik memiliki sifat yang menjanjikan kemakmuran di masa depan. Di negara berkembang, 'pembinaan bangsa' diarahkan pada adanya usaha pembangunan birokrasi yang efektif dan pemantapan sistem kepartaianyangmampumengendalikan peran-serta kelompok-kelompok baru ke arena politik. Sementara itu, pemerintah sebagai instrumen strategis dalam variabel politik yang merupakan struktur kongkret bertindak sebagai fihak yang menjalankan tanggungjawab untuk mempertahankan dan/ ataumengadaptasisistemyangmenjadi bagiannya.Aktivitasutamapemerintah adalah menjalankan tanggung-jawab dengan membuat pilihan-pilihan yang mengikat para anggota sistem. Meskipun demikian, pemerintah tidak hanya merupakan instrumen kunci dari politik tetapi juga mencari keseimbangan antara 'apa masyarakat yang ada' dan 'bagaimana masyarakat yang seharusnya ada'.

\section{Diferensiasi Struktur/Fungsi}

Diferensiasi fungsional merupakam salah satu jenis diferensiasi (sosial), selain diferensiasi tingkatan (rank diferensiation) dan diferensiasi adat (custom diferensiation) ${ }^{102}$. Jika diferensiasi tingkatan muncul karena ketimpangan distribusi barang dan diferensiasi adat muncul karena aturan berperilaku yang tepat berbeda menurut situasi tertentu, maka diferensiasi fungsional atau pembagian kerja muncul karena orang melaksanakan pekerjaan yang berlainan. Diferensiasi mendorong kerangka lembaga umum yang mengkoordinasikan dan mengintegrasikan substruktur di bidang-bidang yang berbeda. Bagaimanapun akibat luas modernisasidalambidangkelembagaan menyebabkan diferensiasi dan interdependensi di antara unit-unit yang saling terkait dalam sistem. Juwono Sudarsono $^{103}$ memberikan gambaran sederhana mengenai diferensiasi struktur dan spesialisasi fungsional dalam modernisasi (politik), yang tampak sebagai segitiga yang terdiri dari tiga faset berbeda dimana satu sisi dengan yang lain saling terkait, seperti pada gambar berikut:

102 Kaare Svalastoga. Diferensiasi Sosial. Bina Aksara. Jakarta, tahun 1989 hal. 1.

103 Juwono Sudarsono. Op.Cit. hal. 9-10.

CosmoGov, Vol.1 No.1, April 2015 173 


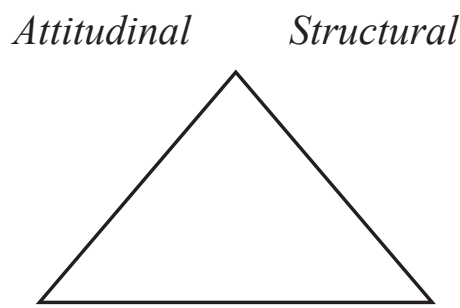

Processual

Gambar 1.1 Struktur Perubahan

Penjelasan:

Faset Struktural mencakup diferensiasi struktur kelembagaan yangdiantaranyameliputipeningkatan diferensiasi dan integrasi strukt ur yang ada serta pengembangan pengaturan institusi secara inovatif; kebangkitan lembaga-lembaga politik baru, pengelompokkan pekerjaan berdasarkan spesialisasi dan profesi, diferensiasi dan spesialisasi pada suatu ketika diperkuat danditopangolehmekanisme pencakupan integrasi perluasan peranan negara dan meningkatnya saling keterkaitan organisasi-organisasi yang berdasarkan spesialisasi.

Faset Attitudinal di antaranya mencakup transformasi sikap tradisional yang didasarkan pada adat dan sistem keyakinan agama menjadi berbagai bentuk rasionalitas sekuler yang didasarkan pada ilmu dan skeptisisme yang terorganisasi, termasuk juga keterbukaan terhadap pengalaman baru dan sikap positif terhadap kehidupan dan alam.

Faset Prossesual diantaranya mencakup spesialisasi fungsional, peranan status baru, gerakan agama dan politik, dan lain-lain yang merefleksikan ketidakseimbangan gerakan diferensiasi dan integrasi.

Pembagian fungsi di kalangan lembaga-lembaga yang secara relatif bersifat khusus juga mendorong timbulnya kepincangan karena lembaga-lembaga tersebut tidak memiliki kekuasaan yang sama. Misalnya, fungsi legislatif atau pembuat undangundang mempunyai lebih banyak kekuasaan dibandingkan dengan fungsi administratif atau pelaksana undang-undang. Lembaga-lembaga pemerintahan dapat mempunyai kekuasaan yang sama atau tidak sama; atau juga mempunyai fungsi yang khusus ataut umpangtindih. Penugasan setiap fungsi di dalam lembagalembaga yang terpisah merupakan salah sat u aspek diferensiasi fungsional yang menjadi ciri khas modernisasi (politik).

\section{Peran-serta Politik Massa}

Perkembangan pengetahuan politik modern saat ini tidak hanya terfokus pada konsep-konsep yang terkait dengan analisis struktur dalam sistem politik saja. Konsep partisipasi politik juga memiliki kedudukan yang sangat penting dalam analisis politik modern, terutama dalam hubungannya dengan negara-negara yang sedang berkembang. Dalam konteks lain, partisipasi politik menjadi aspek yang penting pula dalam kaitannya dengan pembahasan demokrasi. Asumsi ini didasari pada pengertian yang menya- 
takan bahwa partisipasi politik merupakan keikutsertaan warga negara biasa dalam menentukan segala keputusan yang menyangkut atau mempengaruhi hidupnya. ${ }^{104}$ Kesadaran yang meluas akan partisipasi dalam politik merupakan ciri dari masyarakat modern, mengingat masyarakat adalah sumber kekuasaan politik bagi pemerintah. Dalam suatu negara modern, warga negara secara langsung terlibat dalam mempengaruhi pemerintahan. Partisipasi ini sebagian timbul melalui pertumbuhan partaipartai politik dan kelompok-kelompok kepentingan. Perkembangan analisis partisipasi politik melahirkan suatu anggapan bahwa dalam negara-negara modern yang tingkat demokratisasinya tinggi, umumnya dianggap bahwa lebih banyak partisipasi masyarakat maka demokrasi lebih baik. Dalam alam pemikiran ini tingginya tingkat partisipasi politik menunjukan bahwa warganegaramengikutidanmemahami masalah politik dan ingin melibatkan diri dalam kegiatan-kegitan politik. Tetapi di lain pihak, persoalan partisipasi politik ternyata tidak bisa digeneralisasikan secara langsung dalammemandangtingkatanpartisipasi politikwarganegara, bisajaditingkatan partisipasi tiap warga negara akan berbeda-beda. Sehingga, partisipasi politik dipandang memiliki bentuk tertentu dalam memahaminya.

\section{METODOLOGI}

Metode yang digunakan dalam penelitian ini adalah deskriptif, yakni suatu metode yang memusatkan pada pemecahan masalah berdasarkan pada fakta dan kenyataan yang ada pada saat penelitian berlangsung. Adapun pendekatan yang digunakan adalah kuantitatif.

\section{Teknik Pengumpulan Data}

Pengumpulan data adalah prosedur yang sistematik dan standar untuk memperoleh data yang diperlukan. Pengumpulan data merupakan langkah yang penting dalam metode ilmiah, karena data yang dikumpulkan digunakan untuk menguji hipotesa yang telah dirumuskan ${ }^{105}$. Adapun langkah-langkah untuk memperoleh data yang diperlukan dalam penelitian ini, peneliti menggunakan teknik pengumpulan data melalui studi lapangan, yaitu pengumpulan data dengan cara terjun langsung ke lapangan yang menjadi obyek penelitian, yang meliputi: (1) Observasi, yaitu studi yang di sengaja dan sistematis tentang fenomena sosial dan gejalagejala psikis dengan jalan pengamatan dan pencatatan ${ }^{106}$. Kegiatan observasi ini dilakukan di wilayah Pemerintah Kabupaten Bandung dan khususnya di

104 R. Surbakti, Memahami Ilmu Politik, Jakarta: Gramedia Widiasarana. 1992, hlm. 140. 105 Moh. Nazir. Metode Penelitian. Ghalia Indonesia. tahun 1988. Hal. 211.

106 Kartono; tahun 1986; hal. 142. 
wilayah Kecamatan Majalaya. (2) Kuesioner, yaitu teknik pengumpulan data dengan memberikan sejumlah pertanyaan tertulis kepada responden untuk diisi. Kuesioner ini disebar kepada responden yang terdiri dari masyarakat di 11 Desa yang terdapat di wilayah Kecamatan Majalaya, yang terdiri dari Desa Majalaya, Desa Majaserta, Desa Majakerta, Desa Sukamaju, Desa Bojong, Desa Biru, Desa Padaulun, Desa Sukamukti, Desa Wangisagara, Desa Neglasari, dan Desa Padamulya. Jenis kuesioner yang digunakan adalah kuesioner tertutup, artinya responden hanya mengisi pilihan jawaban yang telah tersedia dan tidak dimungkinkan untuk memberi jawaban lain yang tidak tersedia dalam kuesioner.

Wawancara, yaitu suatu proses interaksi dan komunikasi antara pewawancara dan responden mengenai suatu topik penelitian ${ }^{107}$. Teknik wawancara ini dilakukan terhadap pihak-pihak yang dianggap dapat memberikan informasi yang diperlukan dalam penelitian. Adapun fihak-fihak yang berkompeten untuk diwawancarai adalah: aparat di wilayah Pemerintah Kecamatan Majalaya, yang terdiri dari 2 aparat Seksi Perencanaan, 2 aparat Seksi Pemerintahan, 2 aparat Seksi Pengendalian Ketentraman dan
Ketertiban, 2 aparat Seksi Pemeliharaan Sarana Umum, 2 aparat Seksi Pemberdayaan Masyarakat, 2 aparat Seksi Pengembangan Potensi PAD, serta 2 aparat Seksi Informasi dan Kehumasan. Pemilihan fihak yang diwawancarai terkait dengan tema yang diangkat dalam penelitian ini. Kegiatan wawancara dilakukan sebagai petunjuk (guide research) serta untuk melengkapi analisa dari data pengamatan dan data kuesioner sehingga dapat dihasilkan analisa yang obyektif. (4) Dokumentasi, yaitu mencari data mengenai hal-hal atau variabelyang berupacatatan, transkrip, buku, surat kabar, majalah, notulen rapat, dsb ${ }^{108}$. Selain itu, pengumpulan data dilakukan pula melalui Studi Kepustakaan, yaitu pengumpulan data melalui telaah terhadap buku-buku, jurnal, surat kabar, dan sumber informasi tertulis lainnya yang ada hubungannya dengan materi yang dibahas.

\section{Populasi dan Sampel}

Populasi adalah keseluruhan dari karakteristikatauunithasilpengukuran yang menjadi obyek penelitian ${ }^{109}$. Dalam penelitian ini populasi adalah seluruh aparat kecamatan dan seluruh penduduk di Kecamatan Majalaya.

107 Singarimbun; tahun 1995; hal. 192.

108 Arikunto. Hal . 236 tahun 1995.

109 Ridwan \& Tita Lestari. Dasar-dasar Statistika. Alfabeta. Bandung. tahun 2001. Hal. 3.

176 CosmoGov, Vol.1 No.1, April 2015 
Adapun keseluruhan penduduk di wilayah Kecamatan Majalaya adalah 127.019 jiwa, dengan ciri-ciri populasi adalah aparat kecamatan yang terbagi ke dalam beberapa Seksi pada SOTK Pemerintah Kecamat an Majalaya serta Masyarakat yang tercatat sebagai penduduk di wilayah Kecamatan Majalaya.

\section{Teknik Pengambilan Sampel}

Sampel adalah bagian dari populasiyangmempunyaikarakteristik tertentu atau ciri/keadaan yang akan diukur, karena tidak semua data dan informasi akan diproses dan tidak semua orang atau benda akan diteliti melainkancukupdenganmenggunakan sampel yang mewakilinya ${ }^{110}$. Dalam penelitian ini sampel unt uk masyarakat Kecamatan Majalaya yang dianggap mewakili diperoleh dengan menggunakan Rumus dari Tar Yamane:

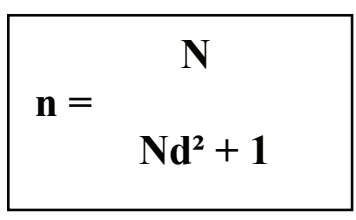

$\mathrm{n}=$ Sampel yang dianggap mewakili

$\mathrm{N}=$ Jumlah Populasi

$\mathrm{d}=$ Presisi, dalam hal ini diambil 10 $\%$
Dengan jumlah populasi 127.019 orang, maka banyaknya sampel:

$$
\begin{aligned}
\mathrm{n} & =\frac{127.019}{127.019(0,1)^{2}+1} \\
& =99,92 、 100
\end{aligned}
$$

Jadi banyaknya sampel untuk masyarakat adalah 100 orang, yang keseluruhannya adalah penduduk di wilayah Kecamatan Majalaya Kabupaten Bandung.

HASIL DAN PEMBAHASAN

\section{Rasionalisasi Kewenangan pada Sistem Pemerintah Kecamatan Majalaya Tahun 2012}

Kedudukanpemerintahkecamatan sebagai perangkat daerah kabupaten dalam penyelenggaraan otonomi daerah menjadi sangat penting. Besarnya wewenang, tugas, dan fungsi yang dilimpahkan Pemerintah Kabupaten Bandung menjadikan Pemerintah Kecamatan Majalaya sebagai salah satu ujung tombak keberhasilan penyelenggaraan otonomi daerah di Kabupaten Bandung.

Kondisi tersebut juga disadari oleh aparat maupun masyarakat. Hal

110 Ibid. Hal. 4. 
ini dapat dilihat dari tanggapan responden. Dari item pertanyaan yang diajukan, seluruh responden (100 orang) menyatakan setuju terhadap adanya perbedaan di antara Seksi-seksi dalam SOTK Pemerintah Kecamatan Majalaya. Perbedaan ini terutama pada penetapan tugas, fungsi, dan kewenangan. Meskipun aparat pemerintah kecamatan menyadari seringkali terjadi overlapping baik dalam pelaksanaan tugas maupun fungsi di antara Seksi-seksi dalam struktur organisasi pemerintahan, akan tetapi kondisi tersebut tidak mengganggu kinerja pemerintahan secara keseluruhan dan bahkan hal itu di anggap sebagai bentuk kerja sama dalam suatu sistem. Pengetahuan responden yang tinggi terhadap kondisi perbedaan tugas maupun fungsi berbagai Seksi dalam SOTK pemerintah kecamatan inimembuktikan, bahwasesungguhnya masyarakat memiliki perhatian terhadap pemerintahan sebagai lembaga yang memiliki mekasnisme kerja berdasarkan struktur organisasi.

Keith Devis dan John W. Newstrom ${ }^{111}$ mengartikan organisasi adalah sistem sosial. Apabila ingin bekerja dalam organisasi atau mengelolanya, maka perlu memahami cara kerjanya. Organisasi mengkombinasikan ilmu dan orang-teknologi dan kemanusiaan. Teknologi sendiri cukup sulit, tetapi apabila menambahkan unsur orang akan memperoleh sistem sosial yang sangat rumit yang hampir-hampir tidak dapat dipahami. Akan tetapi, masyarakat harus memahami organisasi dan memanfaatkannya dengan baik karena organisasi diperlukan untuk mencapai kemaslahatan peradaban. Kelangsungan hidup masyarakat modern bergantung pada organisasi.

Tingginya tingkat pengetahuan masyarakatterhadapSOTKPemerintah Kecamatan Majalaya berdasarkan adanya perbedaan fungsi di antara Seksi-seksi dapat memberikan arah terhadap pemahaman masyarakat pada organisasi pemerintah kecamatan. Sehingga,masyarakat dapat memahami perilaku yang seharusnya dilakukan orang-orang yang terlibat atau mengelola organisasi tersebut. Dalam hal ini masyarakat dapat melakukan kontrol terhadap perilaku aparat Pemerintah Kecamatan Majalaya dalam melaksanakan tugas dan fungsi pelayanannya kepada masyarakat. Karena, sesungguhnya perilaku manusia dalam organisasi agaknya tidak dapat diperkirakan. Selain itu pemahaman terhadap organisasi tidak dapat berhenti pada pengertian organisasi itu sendiri, salah satu yang harus diperhatikan adalah pemahaman terhadap perilaku organisasi yang

111 Keith Davis dan John W. Newstrom; Perilaku dalam Organisasi; Penerbit Erlangga: Jakarta, tahun 1985; hal 4. 
sesungguhnya dapat diterapkan secara luas dalam perilaku orang-orang di semua jenis organisasi seperti bisnis, pemerintahan, sekolah, dan organissi jasa. Artinya, bahwa apapun organisasinya ada kebutuhan untuk memahami perilaku organisasi. ${ }^{112}$

Sementara, tanggapan responden terhadap kemandirian pelaksanaan tugas-tugas pemerintahan semakin diperkuat oleh tingkat kepercayaan terhadap pemerintah di banding terhadap Organisasi Masyarakat/Lembaga Swadaya Masyarakar (Ormas/ LSM). Sebagian besar, yaitu $47 \%$, responden menyatakan setuju terhadap kondisi tersebut. Hal ini dapat difahami jika melihat kondisi Ormas/LSM yang ada di Kecamatan Majalaya yang masih sangat terbatas baik dalam sosialisasi maupun aktivitasnya. Meskipun demikian, responden yang menyatakan ragu-ragu cukup tinggi, yaitu 38\%. Sementara yang tidak menaruh kepercayaan terhadap pemerintah, hanya $15 \%$. Hal ini dimungkinkan terkait dengan kurang responnya pemerintah atas potensi Majalaya terutama sebagai wilayah pengembangan industri. Padahal keterbatasan kewenangan dalam pembangunan industri menjadikan pemerintah kecamatan tidakbisamengambil langkah-langkah strategis untuk mengelola industrinya. Bahkan untuk melakukanpendataanterhadapindustri kecil dan sedang, atau dikenal juga dengan "industri pribumi atau industri lokal", yang mengalami kesulitan dalam perkembangannya, pemerintah kecamat an mengalami kesulitan dalam berkoordinasi dengan pemerintah kabupaten. Adanya BIDIK (barang tekstil), yaitu lembaga yang ditunjuk pemerintahkabupatensebagaipembina atau "bapak angkat" bagi industri kecil dan industri sedang, semakin membatasi kewenangan pemerintah kecamatan.

Meskipun Pemerintah Kecamatan merupakan lembaga yang dipercaya dibandingkan dengan Ormas/LSM, akantetapitingkat kepercayaanmasyarakat pada selain lembaga pemerintah cukup tinggi. Hal ini dapat ditunjukan dengan tanggapan responden terhadap pentingnya peran ulama dan tokohtokoh masyarakat, yang menunjukan $49 \%$ responden menganggap ulama dan tokoh masyarakat tetap sebagai fihak penting dalam kehidupan sosial politik di Majalaya, 38\% menyatakan ragu-ragu, dan hanya $15 \%$ responden saja yang tidak setuju para ulama dan tokoh masyarakat memiliki peranan penting dalam kehidupan sosial politik di Kecamatan Majalaya.

Bagi pemerintah kecamatan, menjaga hubungan komunikasi dan

112 Ibid; hal. 5. 
interaksi yang baik dengan para ulama dan tokoh-tokoh masyarakat sangat membantu dalam menjaga eksistensi danmeningkatkan kepercayaan masyarakat terhadap pemerintah kecamatan. Meskipun para ulama dan tokoh masyarakat tidak memiliki kekuasaan dan kewenangan, akan tetapi pengaruh dankharismanyamampumenempatkan mereka dalam posisi penting dalam kehidupan baik sosial, politik, maupun ekonomi masyarakat. Disadari oleh aparat kecamatan bahwa besarnya kewenangan pemerintah kecamatan tidak serta-merta menempatkan pemerintah sebagai fihak yang lebih berkuasa at as fihak atau kelompok lain di Kecamatan Majalaya. Menjadi kebiasaan bagi pemerintah kecamatan untuk mensosialisasikan program atau kegiatan pemerintahan melalui pengajian-pengajian yang rutin dilakukan dari mulai tingkat RT, RW, sampai Desa. Karena, sarana yang dianggap paling efektif untuk menyampaikan informasi kepada masyarakat adalah melalui masjid atau surau/mushola.

Kondisi tersebut difahami oleh pemerintah kecamatan sebagai salah satu cara untuk menjaga "silaturahmi baik" dengan para ulama (ajengan), tokoh masyarakat lainnya, dan masyarakat. Akan tetapi menjelang pemilu/pilkada, ada anggapan bahwa para ulama dan tokoh masyarakat melibatkan diri dalam aktivitas partai politik, meskipun hal tersebut masih sebatas sebagai isu atau rumor politik yang memanfaatkan kharisma para ulama (ajengan) untuk menarik minat masyarakat melakukan pilihan terhadap partai tersebut.

\section{Diferensiasi Struktur/Fungsi pada Sistem Pemerintah Kecamatan Majalaya Tahun 2012}

Sesungguhnya antara masyarakat dan pemerintah terdapat suatu jarak. Jarak tersebut nampaknya adalah suatu akibat yang tidak dapat dihindari dari suat u perbedaan peran yang menyebabkan pembagian kerja yang mutlak antara pemerintah dan masyarakat. Hoogerwerf ${ }^{113}$ menjelaskan bahwa pembagian kerja di suatu fihak dan besarnya jumlah warga (masyarakat) di fihak lain mengakibatkan bahwa hanya sedikit atau hampir tidak ada hubungan langsung antara para warga (masyarakat) dan pemerintah. Apabila jarak tersebut tidak dijembatani, maka mudah terjadi gangguan hubungan antara pemerintah dan masyarakat. Oleh karena itu perlu adanya pemahaman dari kedua fihak atas masing-masing kondisi baik pemahaman terhadap peran dan kewajiban maupun terhadap beban kerja.

113 Hoogerwerf; Op. Cit. Hal. 231.

180 CosmoGov, Vol.1 No.1, April 2015 
Pembagian kerja atau fungsi yang merupakan salah satu indikator dari aspek diferensiasi struktur/fungsi pada konsep modernisasi politik dapat digunakan untuk menjelaskan jarak antara masyarakat dan pemerintah ini. Tingkat pemahaman masyarakat terhadap pemerintah dapat dilihat melalui pengetahuan masyarakat terhadap kejelasan fungsi maupun posisi dari masing-masing seksi dalam struktur organisasi pemerintah. Pada kejelasan fungsi-fungsiSOTK PemerintahKecamatanMajalaya,didapatkan hasilternyata sebagian besar responden (74\%) menganggap bahwa Seksi-seksi dalam SOTK Pemerintah Kecamatan Majalaya tidak memiliki fungsi yang jelas dan terperinci. Sementara, 19\% responden meragukannya dan hanya $7 \%$ responden saja yang setuju. Kondisi tersebut menggambarkan minimnya pengetahuan masyarakat akan fungsi dari Seksi-seksi pada SOTK Pemerintah Kecamatan Majalaya. Kondisi ini berbalik dengan pengetahuan masyarakat terhadap adanya perbedaan di antara Seksi-seksi dalam Struktur Organisasi PemerintahanKecamatan.Halinidimungkinkan karena akses masyarakat terhadap informasi mengenai fungsi/tugas Seksi-seksi tidak terbuka. Tidak ada saranainformasi/pengumuman mengenai hal tersebut, sementara sarana informasi berupa papan informasi yang terpampang dengan jelas hanya mengenai bagan Struktur Organisasi Pemerintah Kecamatan Majalaya.

Bagi Pemerintah Kecamatan, mi- nimnya pengetahuan masyarakat terhadap fungsi dari Seksi-seksi dalam Struktur Organisasi Pemerintah Kecamatan Majalaya tidak mengganggu kinerja masing-masing Seksi, karena umumnya masyarakat jika membut uhkan bantuan pemerintah kecamatan untuk menyelesaikan kepentingannya akan diarahkan oleh sekretariat kecamatan sesuai dengan kebutuhan kepentingannya. Di fihak lain, masyarakat pun tidak memberikan keluhan terhadap kondisi tersebut. Hal ini menunjukan bahwa masyarakat 'tidak peduli' terhadap formalitas fungsi dari masing-masing Seksi, yang penting bagi masyarakat adalah, segala kebutuhan maupun kepentingan yang memerlukan hubungan dengan kecamatan dapat terselesaikan dengan baik.

\section{Peran-serta Politik Massa pada Sistem Pemerintah Kecamatan Majalaya Tahun 2012}

Salahsatuciripentingmodernisasi politik adalah keterlibatan masyarakat dalam berbagai aktivitas, terutama untukmenunjangtugas-tugas pemerintahan. Partisipasi juga terkait dengan program pemberdayaan masyarakat sebagai prasyarat penting keberhasilan penyelenggaraan otonomi daerah. Ada berbagai bentuk untuk mengukur peran-sertamasyarakat dalampemerintahan. Seperti halnya di wilayahwilayah lain, di Kecamatan Majalaya partisipasi massa dilakukan dengan berbagai cara, misalnya dalam pengamanan dan ketertiban wilayah. 
Meskipun tanggung-jawab ada pada Seksi Penertiban dan Keamanan, akan tetapi swadaya masyarakat untuk ikut terlibat cukup tinggi, seperti data dari kepala seksi Trantrib Pemerintah Kecamatan Majalaya bahwa selama semester 1 tahun 2011-2012, tidak ada gangguan yang berarti baik gangguan secara sosial, politik, maupun yang berdasar pada motif ekonomi. Bahkan ketikaterjadikendalabiayaoperasional untuk pengamanan, terutama pada pelaksanaan rangkaian Pilkada Kabupaten Bandung di Kecamatan Majalaya, dapat diatasi secara swadaya oleh masyarakat.

Saat ini, semangat masyarakat Majalaya dalam mensukseskan pemilihan umum (pemilu), baik pemilu legislatif maupun pemilu presiden, menjadi salah satu indikator dalam menjelaskan bentuk partisipasi massa. Penjagaan terhadap keamanan lingkungan dalam masa sosialisasi maupun kampanye partai politik sangat didukung oleh kepedulian masyarakat terhadap suksesnya pemilu/pilkada di lingkungan masing-masing. Pemerintahkecamatanmengakuikesuksesan pemiludiwilayahKecamatan Majalaya adalah karena partisipasi politik masyarakat selama masa sosialisasi, kampanye, dan saat pencoblosan; bahkan pada saat rekapitulasi penghitungan suara di PPK pun sangat aman dan terkendali.

Sementaradisektorindustrimasih perlu mendapat perhatian, terutama bagi sektor-sektor industri kecil dan sedang yang setelah pemberlakukan UU No. 22 Tahun 1999 dan UU No.32 Tahun 2004, tanggung-jawab pembangunan industri dilimpahkan sepenuhnya kepada Pemerintah Kabupaten Bandung dari Departemen Perindustrian dan Perdagangan Provinsi Jawa Barat. Dengan demikian, Pemerintah Kecamatan Majalaya pun dikondisikan menanggung beban dalam mendorong pembangunan industri karena pelimpahan tugas dari Pemerintah Kabupaten Bandung. Bahkan saat ini, berdasarkan Rencana Pembangunan Wilayah Kabupaten Bandung, Kecamatan Majalaya dimasukkan ke dalam wilayah pembangunan industri. Artinya, ada harapan terhadap pembangunan indutri sebagai salah satu faktor pendorong pemberdayaan masyarakat di sektor ekonomi. Perlu juga diketahui, Kecamatan Majalaya merupakan Kecamatan yang memiliki industri paling banyak di Kabupaten Bandung, akan tetapi menurut pemerintah kecamatan, industri di Kecamatan Majalayajustrumengalami penurunan kurang lebih dalam 10 tahun ini, sehingga saat ini fokus pembangunan akan kembali diarahkan pada wilayah industri.

Seperti dijelaskan di awal pembahasan, bahwa berbagai bentuk partisipasimasyarakat dapat ditemukan di wilayah Kecamatan Majalaya, akan tetapi perlu juga diperhatikan inisiatif Pemerintah Kecamatan Majalaya untukmelibatkanlangsung masyarakat dalam pengambilan keputusan, seperti kegiatan rapat-rapat atau pun kegiatan 
lainnya. Untuk mengukur sejauhmana masyarakatterlibat dalampengambilan suatu keputusan, diperoleh hasil dari 100 responden, ternyata hanya $21 \%$ nya yang selalu ikut menghadiri rapatrapat, dan 21\%-nya justru tidak pernah ikut sama sekali. Sementara, yang kadang ikut kadang tidak terdapat $58 \%$. Kondisi tersebut menunjukan masih adanya harapan terhadap tumbuhnya apresiasi masyarakat dalam kehidupan pemerintahan; kondisi ini tidak dapat ditemukan dalam kondisi lemahnya tingkat kepercayaan masyarakat terhadap pemerintah.

Dalam rangka penyelengga-raan otonomi daerah, Pemerintah Kecamatan Majalaya sedang merumuskan suatu bentuk komunikasi dan penyebaran informasi yang efektif kepada masyarakat dengan harapan dapat membangun gagasan-gagasan pembangunan sesuai dengan aspirasi masyarakat.Momenpilkadakabupaten menjadi momen politikyang digunakan pemerintah kecamatan untuk memulai interaksi pemerintah dengan masyarakat. Misalnya dalam rangkaian proses pilkada,banyakwargayangmendatangi pemerintah kecamatan untuk kepentingan pilkada dan kondisi tersebut dimanfaatkan untuk mensosialisasikan program-program pemerintah kecamatan.

Salah satu tujuan pemerintah kecamatan dalam melibatkan masyarakat pada kegiatan-kegiatan, seperti rapat-rapat atau bahkan pengajian pemerintah setiap hari
Jumat, adalah sebagai salah satu upaya "pembinaan" untuk meningkatkan kesadaran masyarakat dalam memahami potensi wilayahnya. Sebagai wilayah yang memiliki potensi industri yang menonjol di Kabupaten Bandung, konsentrasi pembangunan industri diarahkan pada industri kecil dan sedang yang melibatkan sebagian besar masyarakat sebagai pelaku utama. Kondisi tersebut ternyata tidak mempengaruhi kepedulian masyarakat dalam pembicaraan-pembicaraan yang bersifat politik.

\section{SIMPULAN}

Beberapa simpulan berhasil dirumuskan.

Pertama, Wilayah Kecamat-an Majalaya merupakan salah satu wilayah yang memiliki karakteristik dan potensi industri di Kabupaten Bandung. Sehingga, dengan kondisi tersebut terjadi pula masa perubahan dari masyarakat yang menitikberatkan pada sektor pertanian dan peternakan menuju ke arah masyarakat industri. Kondisi ini menunjukan arah modernisasi yang dialami masyarakat Majalaya dalam perkembangan lingkungan domestik maupun global.

Kedua, Penetapan wilayah Kecamatan Majalaya sebagai wilayah industri dalam Rencana Pembangunan Wilayah Kabupaten Bandung memerlukan kesiapan baik suprastruktur maupun infrastruktur oleh pemerintah 
kecamatan karena pelimpahan tugas, fungsi, dan wewenang yang banyak dari Pemerintah Kabupaten Bandung untukmelaksanakan program-program pemerintahan dalam rangka otonomi daerah, seperti yang telah diatur dalam UU No. 32 Tahun 2004 tentang Pemerintahan Daerah yang menitikberatkan pelaksanaannya pada pemerintah kabupaten. Sementara kedudukan pemerintah kecamatan sebagai perangkat daerah kabupaten, Kecamatan Majalaya adalah wilayah kerja camat sebagai perangkat Daerah Kabupaten Bandung. Artinya, pemerintah kecamatan bukan lagi menjadi wilayah administrasi dalam rangka dekonsentrasi tetapi menjadi wilayah desentralisasi, sehingga memiliki tanggung-jawab dalam mengembangkan potensi wilayahnya untuk pemberdayaan masyarakat dalam rangka otonomi daerah.

Ketiga, Tuntutan terhadap peran Pemerintah Kecamatan Majalaya sebagai agen penting dalam proses perubahan menuju ke arah modern memerlukan kondisi yang harus dipenuhi oleh pemerintah kecamatan, yaitu dengan melakukan upaya modernisasi politik bagi SOTKpemerintah kecamatan. Maka, upaya ke arah tersebut dilakukan dengan mengoptimalkan kinerja tujuh Seksi yang terdapat dalam lingkup pemerintah kecamatan, yaitu dengan mengupayakan kejelasan tugas/fungsi dan wewenang serta interaksi di antara Seksi-seksi tersebut, serta dengan mengupayakanperan-sertamasyarakat, yaitu dengan menjalin "silaturahmi" yang intinya jalinan komunikasi dan membuka diri bagi kebutuhan dan kepentingan masyarakat.

Keempat, Berdasarkan aspek rasionalisasi kewenangan, asfek diferensiasi struktur/fungsi, dan asfek peran-serta politik massa yang merupakan kategori dari teori modernisasi politik seperti yang dirumuskan oleh Huntington, maka kondisi modernisasi politik pada sistem pemerintah Kecamatan Majalaya tahun 2012 masih belum memadai dalam mendorong proses industrialisasi.

Kendala-kendala seperti sistem administrasi kecamatan yang tidak rapih, tidak tersusun secara sistematis, dan tidak adanya kejelasan programprogram kerja dari masing-masing Seksi serta rendahnya pemahaman terhadap tugas dan fungsi dari aparat pada masing-masing Seksi tersebut merupakan faktor utama terhambatnya proses modernisasi politik pada sistem pemerintah Kecamatan Majalaya. Selain itu, rendahnya respon masyarakat terhadap keberadaan dan peranan dari Ormas/LSM yang disebabkan oleh minimnya sosialisasi atas keberadaan serta kurang efektifnya aktivitasmaupunadanyaketidakjelasan program dari masing-masing Ormas/ LSM yang terdapat di Kecamatan Majalaya semakin menghambat proses modernisasi politik. Sementara, partai politik yang ada di Kecamatan Majalaya pun belum dapat berperan sebagai lembaga alternatif yang 
mampu memenuhi kebutuhan maupun kepentingan baik politik, ekonomi, maupun sosial masyarakat sehingga keberadaannya hanya terasa penting ketika momen pemilu saja.

Dengan demikian bahwa melihat secaraformalpembentukanpemerintah Kecamatan Majalayayangberdasarkan pada Peraturan Daerah No 07 Tahun 2001; mulai dariSOTK pemerintahnya, adanya penetapan seksi-seksi dengan tugas, fungsi, dan kewenangan masingmasing maka proses modernisasi politik pada sistem pemerintah Kecamatan Majalaya telah terjadi karena modernisasi memerlukan prasyarat struktural yang jelas dan formal. Akan tetapi, apabila dilihat dari kesiapan suprastrukt ur dimana mekanisme kerja maupunkinerjaPemerintahKecamatan Majalaya yang rendah; seperti terdapat ketidakjelasan program dari masingmasing seksi, sistem administrasi dan sistem birokrasi yang tidak sistematis; serta lemahnya kekuatan infrastruktur yang ditunjukan dengan lemahnya peranan dan fungsi baik Ormas/LSM maupun partai politik, maka sesungguhnya prasyarat modernisasi politik pada sistem pemerintah Kecamatan Majalaya tahun 2012 belum terpenuhi.

\section{DAFTAR PUSTAKA}

Arikunto, S., 2012. Prosedur Penelitian: Suatu Pendekatan Praktik. Edisi Revisi cetakan ke12. Jakarta: PT Rineka Cipta.
Apter, E. David, 1987. Pengantar Analisa Politik. Jakarta: PT Gramedia.

------, 1987. Politik Modernisasi. Jakarta: PT Gramedia.

Budiardjo, Miriam, 1999. Dasardasar Ilmu Politik. Jakarta: PT Gramedia Pustaka Utama.

------, 1998. Partisipasi dan Partai Politik: Sebuah Bunga Rampai. Jakarta: Yayasan Obor Indonesia.

Chilcote, H. Ronald, 2003. Teori Perbandingan Politik: Penelusuran Paradigma. Jakarta: PT Raja Grafindo Persada.

Dahrendorf, Ralf, tt. Konflik dan Konflik dalam Masyarakat Industri. Jakarta: CV Rajawali.

Duverger, Maurice. 1981. Sosiologi Politik. Jakarta: Rajawali Press.

Faisal, Sanapiah, 1995. Format-format Penelitian Sosial: Dasar-dasar dan Aplikasi. Yogyakarta: Gajah Mada University Press.

Fuchan, Arif, 1992. Pengantar Metode Penelitian Kualitatif. Surabaya: PT Usaha Nasional.

Haferkamp, Hans \& Smellser, tt. Social Change and Modernity (Perubahan Sosial dan Modernitas. Terjemahan dilakukan oleh Program Studi Ilmu Sosial. Bidang Kajian Utama Sosiologi Antropologi.

Hague. Paul, 1995. Merancang Kuesioner. Jakarta: Pustraka Binaman Presindo.

Huntington, P. Samuel, 2003. Benturan Antar Peradaban dan Masa DepanPolitik Dunia. Yogyakarta: 
Qalam.

------, 1983. Tertib Politik dalam MasyarakatyangSedangBerubah; Jilid II. Jakarta: Rajawali Pers.

Kaho, Josep Riwu, 1990. Prospek Otonomi Daerah di Negara Republik Indonesia. Jakarta: Rajawali.

Lauer, H. Robert, 1993. Perspektif tentang Perubahan Sosial. Jakarta: Rineka Cipta.

Laeyendecker, L., 1991. Tata, Perubahan, dan Ketimpangan. Jakarta: PT Gramedia Pustaka Utama.

M., Katz Saul, 1992. Modernisasi Administrasi untuk Pembangunan Nasional. Jakarta: Rineka Cipta.

Natzir, M., 1988. Metode Penelitian. Jakarta: Ghalia Indonesia.

Nawawi, Hadari dan Nartini Nawawi, 1992. Instrumen Penelitian Bidang Sosial. Yogyakarta: Gadjah Mada University Press.

Ridwan dan Tita Lestari, 2001. Dasardasar Statistika. Bandung: Alfabeta.

Schoorl, J.W., 1991. Modernisasi: Pengantar Sosiologi Pembangunan Negara-negara Sedang Berkembang. Terjemahan R.G. Soekadijo. Jakarta: Gramedia.

Sudarsono, Juwono, 1981. Pembangunan Politik dan Perubahan Politik: Sebuah Bunga Rampai, Jakarta: PT Gramedia.

Sugiyono, 2001. Statistik Non Parametris untuk Penelitian. Bandung: Alfabeta.
Sujamto, 1990. Perspektif Otonomi Daerah. Jakarta: Rineka Cipta.

Siegel, Sydney, 1997. Statistik Nonparametrik untuk Ilmu-ilmu Sosial. Cetakan Kesepuluh. Jakarta: Gramedia Pustaka Utama.

Singarimbun, M. \& Effendi S., 1987. Metode Penelitian Survai. Jakarta: LP3ES.

Syafrudin, Ateng, 1976. Pengaturan Koordinasi Pemerintahan di Daerah. Bandung:Tarsito.

The Liang Gie, 1967. Pertumbuhan Pemerintahan Daerah di Negara Republik Indonesia. Jakarta: Gunung Agung.

Wayong J., 1975. Asas-asas dan Tujuan Pemerintahan Daerah. Jakarta: Djambatan.

\section{Peraturan Perundang-undangan:}

Undang-undang No. 32 Tahun 2002 tentang Pemerintahan Daerah.

Buku 3 (Tiga) Keputusan Bupati No. 37 Tahun 2003 tentang Himpunan Petunjuk Pelaksanaan/Petunjuk Teknis Keputusan Bupati No. 21 Tahun 2001 tentang Pelimpahan Sebagian Kewenangan Bupati Kepada Camat.

\section{Sumber Lainnya:}

DataMonografiPemerintahKabupaten Bandung Kecamatan Majalaya.

Data Potensi Perusahaan Industri Manufaktur Formal Non Fasilitas di Kabupaten Bandung. 
Statistik: Industri Besar dan Sedang Kabupaten Bandung Tahun 1996. BPS Kantor Statistik Kabupaten Bandung.

Proyeksi Penduduk Kabupaten Bandung, Kerjasama antara BadanPerencanaanPembangunan Daerah (Bappeda) DT II
Kabupaten Bandung dan Kantor Statistik Kabupaten Bandung.

Data Potensi Perusahaan Industri Manufaktur Formal Non Fasilitas di Kabupaten Bandung. Dinas Perindustrian dan Perdagangan Pemerintah Kabupaten Bandung. 